\title{
"IN THIS OUR LIGHTYE AND LEARNED TYME": ITALIAN BATHS IN THE ERA OF THE RENAISSANCE
}

\author{
Richard Palmer
}

The sixteenth century saw a transformation in medicine as it came to be dominated by the ideals and methods of the Renaissance. ${ }^{1}$ The recovery of lost texts, and the availability in print of a wide-ranging medical literature from the ancient world, aroused overwhelming enthusiasm. The first phase of this development, marked above all by the printing of the works of Galen in Greek and of a flood of Latin translations, was complete by the mid-century. Medicine, and especially its literature, had put on a new cultural dress. Further change was nevertheless to come in the second half of the century as particular branches of medicine were re-explored in the light of the classics and brought into the mainstream of the medical Renaissance.

Amongst the specialisms which physicians sought to re-clothe in the new Renaissance fashion was balneology. Here, however, there were problems. Medicinal waters, as certain Renaissance doctors admitted, were more an empiric than a rational therapy. Common experience, trial and error, were the guides to their use, and even responsible for their first introduction. Gabriele Falloppia argued so in his lectures De medicatis aquis at Padua in 1556. He pointed out that the discoverer of the Aqua Brandola in 1448 was none other than a diseased cow which chanced to drink the health-giving water. ${ }^{2}$ Worse still, neither Galen nor any of the other classical princes of medicine had written at length on the subject. Why, asked Andrea Bacci, was Galen so negligent? Why did he not get his feet wet? ${ }^{3}$ Falloppia, too, noted that Galen wrote very little about baths, and coldly at that. Galen, he argued, liked to link reason and experience and to support one with the other; he had little faith in medicinal waters which were a purely empiric therapy. ${ }^{4}$ Accordingly, some of the early champions of Renaissance medicine, notably Giovanni Manardi and Matteo Corti, were lukewarm, or even hostile, to the baths. ${ }^{5}$

Richard Palmer, Ph.D., A.L.A., Wellcome Institute for the History of Medicine, 183 Euston Road, London NW1 2BN.

\footnotetext{
${ }^{1}$ See especially A. Wear, R. K. French, and I. M. Lonie (eds.), The medical renaissance of the sixteenth century, Cambridge University Press, 1985.

2 Gabriele Falloppia, De medicatis aquis atque de fossilibus, Venice, 1564, f. 38r.-v. Cf. G. E. Ferrari, 'L'opera idro-termale di Gabriele Falloppio: le sue edizioni e la sua fortuna', Quaderni per la Storia dell'Università di Padova, 1985, 18: 1-41.

${ }^{3}$ Andrea Bacci, De thermis, Venice, 1571, pp. 77-8.

${ }^{4}$ Falloppia, op. cit., note 2 above, f. 39r.-v.

5 On Manardi, see Bacci, op. cit., note 3 above, p. 80 et seq.; on Corti, see De balneis omnia quae extant, Venice, 1553, f. 198r.
} 


\section{Italian Renaissance baths}

The tide began to turn with the publication in 1553 of an encyclopaedic work which brought together, in its 497 folio pages, the bulk of the extant literature, both ancient and modern, on medicinal waters. Ambitiously entitled De balneis omnia quae extant, it was the work of the Venetian Giunta press, which had already brought out the most popular edition of Galen in Latin. Parts of De balneis were specially commissioned by Tommaso Giunta, ${ }^{6}$ and he included a compendium of all the scattered comments of Hippocrates and Galen on the subject. Taken together, these totalled a semirespectable 40 pages. The book also demonstrated from later writers, such as Oribasius and Aetius, the importance of bathing in late antiquity. Archaeological evidence was also pressed into service. Gian' Antonio Secco, who practised as a physician in Venice, contributed an elegant drawing of a Roman bath house, and he urged his readers to "confirm and perfect ancient medicine not only in words, but in use, so that the baths of the ancients, now at death's door, may be restored to public use and live again". 7

This theme was also taken up by Andrea Bacci. At a time when medicine had been restored to its antique splendour, it was impious, he argued, to leave the baths uncared for. In the 509 folio pages of his De thermis (Venice, 1571), which he illustrated with a plan of the Baths of Diocletian, he strove to teach the art of the baths from Galen and the Aristotelians. He also sought to show that taking the waters was not, after all, a matter of rank empiricism. Rather it was a discipline, balneology, with its own rationale, institutes, and doctrine, which the learned physician alone was qualified to understand. ${ }^{8}$ The theme of Renaissance also loomed large in Bacci's separate treatise on the Acque Albule at Tivoli. Here he claimed a share of the credit for rediscovering the baths of the Emperor Augustus. These waters, he wrote, known to the ancients but overlooked for hundreds of years, had now been brought back to light for the good of all. ${ }^{9}$

Taking the waters could thus be presented in the later sixteenth century as another of the arts which were undergoing renewal after a long, dark age of neglect. This powerful Renaissance dialectic so influenced later generations that, by the nineteenth century, Jules Michelet could write disdainfully of the Middle Ages as "mille années sans un bain". ${ }^{10}$ His phrase, however, succeeded more by wit than wisdom. The late Middle Ages were, in fact, a period of active, and growing, interest in the therapeutic use of waters. Surviving manuscripts of Peter of Eboli's thirteenth-century poem on

\footnotetext{
${ }^{6}$ A letter from Tommaso Giunta to Francesco Frigimelica at Padua, 12 July 1552, soliciting a new contribution on the baths of Abano, survives in Padua, Archivio Antico dell'Università, filza 421, f. 1 r.-v.

${ }^{7}$ De balneis, op. cit., note 5 above, f. 489. Archaeological and antiquarian interest in Roman baths was also promoted by Guillaume Du Choul, Discours sur la castramétation et discipline militaire des Romains ... Des bains et antiques exercitations, Lyon, 1556-57, of which an illustrated Italian version was published at Padua in 1559. An illustration of Roman bathing also appeared in Girolamo Mercuriale, De arte gymnastica, 2nd, illustrated, ed., Venice, Giunta, 1573.

${ }^{8}$ Bacci, De thermis, op. cit., note 3 above, p. 80.

${ }^{9}$ Andrea Bacci, Discorso delle Acque Albule, bagni di Cesare Augusto a Tivoli, Rome, 1567.

${ }^{10}$ For a critique of Michelet's comment, see Giorgio Bellagarda, "Il trattato cinquecentesco "De balneis"', Congresso Italiano di Studi Storici Termali, 1, Salsomaggiore Terme, 1963, pp. 92-102.
} 


\section{Richard Palmer}

the thermal baths of the volcanic region of Pozzuoli, near Naples, and the lavish illustrations of bathing which they contain, testify vividly to the popularity of medieval baths. ${ }^{11}$ Peter described 35 separate baths, each with particular properties for the cure of a wide variety of conditions. These were Roman bath houses, dilapidated, but still in use-evidence of continuity with the ancient world. At the same time new baths, unknown to the Romans, were becoming popular, notably Porretta in the territory of Bologna. ${ }^{12}$ The correspondence of Italian laymen such as the mercantile Datini family of Prato, read alongside medical consilia and treatises, show that the baths were a widely-used resource in the fourteenth and fifteenth centuries. ${ }^{13}$ The waters of the territory of Padua alone were the subject of three major treatises by professors at the local University, Giovanni de' Dondi, Bartolomeo da Montagnana, and Michele Savonarola. Even a Renaissance writer like Andrea Bacci grudgingly admitted their worth, given what he called the "mediocrity of the times", and Tommaso Giunta included them in De balneis, while deploring that they were not altogether to contemporary taste. ${ }^{14}$

Renaissance writers on balneology were not, then, reviving a therapy which had fallen into disuse. On the contrary, it was the very popularity in the sixteenth century of taking the waters-Bacci referred to the "tumultuous concourse of men to the baths"-which aroused these writers' concern. Underlying De thermis was Bacci's belief that bathing had escaped from medical control into the hands of laymen. The book appealed not simply for the restoration of classical spas, but for a methodical approach to their use, in keeping with the canons of ancient medicine. ${ }^{15}$

Therapy at the baths, pursued with due method, was necessarily complex. The waters themselves had first to be understood, and their mineral content analysed. Distilling was used in research to this end from at least the fifteenth century, although analysis of the residues into proportions of iron, sulphur, salt, chalk, saltpetre, and other minerals remained rudimentary and sometimes controversial. Gabriele Falloppia, for instance, could agree neither with past generations nor with his contemporaries on the mineral content of the baths of Abano in the territory of Padua. ${ }^{16}$ Second it was important to know the quality of each mineral and its effect on the body-heating or cooling, drying, purging, softening and so on. Thought was

${ }^{11}$ C. M. Kauffmann, The baths of Pozzuoli. A study of the medieval illuminations of Peter of Eboli's poem, Oxford, Bruno Cassirer, 1959. The oldest, thirteenth-century, illuminated manuscript is available in facsimile: Petrus de Ebulo, Nomina et virtutes balneorum . . . codice Angelico 1474, con introduzione di A. D. Lattanzi, Rome, Istituto Poligrafico dello Stato, 1962.

${ }^{12}$ Giulio Gentili, 'I più antichi documenti sulle terme di Porretta (secoli xiii-xiv)', Congresso Europeo di Storia della Medicina, I, Montecatini Terme, 1962, pp. 236-44, with useful documentation of the management of the baths by the Comune. Bacci noted that the popular baths of Viterbo, Siena, Pisa, and Lucca were unknown to the ancients (op. cit., note 3 above, p. 79).

${ }^{13}$ Federico Melis, 'La frequenza alle terme nel basso medioevo', Congresso Italiano, op. cit., note 10 above, pp. $38-49$.

${ }^{14}$ Bacci, op. cit., note 3 above, p. 80. Giunta, op. cit., note 6 above, stated that the works of da Montagnana and Savonarola "non sodisfano in tutto all' ingegni presenti".

${ }^{15}$ Bacci, op. cit., note 3 above, p. 80.

${ }^{16}$ Falloppia, op. cit., note 2 above, ff. 68-70. Bacci, op. cit., note 3 above, pp. $238-40$. 


\section{Italian Renaissance baths}

also needed as to which parts of the body might be influenced by taking the waters. Did drinking mineral water affect only the bodily channels through which the water passed, or were its effects wider? ${ }^{17}$ Then the variety of hydro-therapeutic methods had to be considered. The effects of the waters could be mediated by bathing, drinking, by their use in cooling or diluting wine, by clysters, douches into the womb, fomentations, showers directed on to the affected part, hot mud applied and left to cool, cold mud applied and left to warm and dry in the sun, or by hot fumes designed to purge by sweating or to dry the womb in gynaecological disorders. Ingenious therapies, such as injecting the water into the nasal passages, could be devised to suit particular conditions or parts of the body.

Knowledge of each ailment and its cause, and of the patient's constitution, was also necessary, in the view of the Renaissance physician, before he could advise on which bath (or combination of baths) to choose, which therapy (or therapies) to pursue, and which rules for diet and life-style to follow while taking the waters. Noble patients often took one or two doctors with them to the baths, and, Andrea Bacci argued, such advice was essential. In his view, a healthy man who used the baths inadvisedly risked his health, the sick man his life. For the baths could kill as well as cure, with a range of side-effects from headache to convulsions, excessive sweat, fever, and vomiting. ${ }^{18}$

Few, however, seem to have heeded such warnings. "How many today", lamented Bacci, "go to the baths on the doctor's advice rather than at the suggestion of some layman?". He condemned widespread licence at the baths, where each bather did his own thing. ${ }^{19}$ Conrad Gesner made a similar point about the baths of Switzerland in his contribution to De balneis. There, to quote William Turner's translation, "The most parte having no regard nether unto the time nor unto mesure gluttenusly eat both in the bath and out of it ... Some there be whych lyke unto duckes continue day and night in the bath." ${ }^{20}$ Michel de Montaigne, who toured the baths of Italy in 1581 in search of a cure for the stone, was especially independent. At the baths of Lucca he took a perverse pleasure in drinking and bathing together rather than in separate sequences of days, bathing once a day rather than twice, showering for short rather than long periods, and choosing waters other than those in normal use. He discarded the urine flask used by patients in an attempt to balance intake and excrements. "C'est une sotte costume," he wrote, "de conter ce qu'on pisse". He also enjoyed the fierce disagreements between doctors over medicinal waters. "Of twenty consultations", he claimed, "there were not two in agreement, each doctor damning the other and accusing him of murder". 21

Many bathers therefore preferred to follow one of the numerous advice books which set out the virtues and uses of each spa. Although dismissed by Andrea Bacci as

\footnotetext{
${ }^{17}$ Falloppia, op cit., note 2 above, f. 43.

18 Bacci, op. cit., note 9 above, p. 11.

19 Bacci, op. cit., note 3 above, p. 80.

20 William Turner, $A$ booke of the natures and properties as well of the bathes in England as of other bathes in Germanye and Italye, Cologne, 1568, ff. 5v. $-6 \mathrm{v}$.

${ }^{21}$ Michel de Montaigne, Journal du voyage de Michel de Montaigne en Italie, (ed. Alessandro d'Ancona, Città di Castello, 1895): especially pp. 415-18, 438-9. Montaigne's scorn for formal medicine-"La vaine chose que c'est que la médecine!"-evidently did not extend to the baths themselves.
} 
"municipalia compendia", local studies without system or general relevance, they had at least the virtue of simplicity. ${ }^{22}$ Typical was the compendium on the baths of Caldiero written in the vernacular and published at Verona in 1594. The author was Ventura Minardo, who was not a physician, but a member of a religious order. ${ }^{23} \mathrm{His}$ book described the two baths at Caldiero, which were maintained, indirectly, by the town council of Verona. The first, used for both drinking and bathing, was walled around, with steps and benches for seating, and with a paved floor which had been laid down at the time of a visit by the-Marquis of Mantua in 1524. The second was open, used by bathers with skin conditions such as scabies, for the veterinary bathing of animals, and for washing off therapeutic mud (since it was incivile to do so in the walled bath). Caldiero's warm water had a mainly iron content, with lesser proportions of sulphur and saltpetre, and its effects were thought to be drying and slightly cooling. It was therefore useful for all diseases caused by excessive moisture such as joint pains, gout, dropsy, swellings, flux, catarrh, weeping eyes, infertility, and gonorrhoea. But Minardo's list was not restrictive, for he named no fewer than 78 conditions which might benefit. The season at Caldiero lasted from mid-June to August. Bathers were advised to take a room near the baths, and to bring drinking glasses, a urine flask, an instrument for clysters (Montaigne's landlord at Lucca proved to be a dab hand at administering these), and a supply of toilet paper. ${ }^{24}$ Therapy began with a purgative and a day of rest. On the next day patients might drink up to five cups of water, increasing day by day to the maximum bearable, in the order of 10 to 20 cups. The dose was then progressively diminished. Minardo thought that 20 days were needed for the cure-twelve drinking, eight drinking and bathing. Provision for showering was primitive, in the form of a raised shower bucket from which water could be directed on to the head while standing in the bath. Caldiero mud was especially good for skin diseases. On the fifth day of water therapy the patient might apply the thick, black, sticky mud to the affected part, leaving it to dry in the sun while keeping the rest of the body under a shade. The mud was then washed off, and the procedure repeated three or four times. Return visits to Caldiero were recommended, for the water was said to act in the first year as a syrup, but in the second as a medicine. Taken every year for 15 days, it was said to be a veritable fountain of youth.

Bathing was meant to be a pleasant experience. Essential to the cure, according to Bacci, was a quiet orderly life in pleasant surroundings, good food and wine, and a maximum of comfort. Bathing and comfort were, in his view, synonymous: "Qui dicit balneum dicit comodum". For that reason, he argued, it was no use for the poor to go to the baths, where they could only do themselves harm. ${ }^{25}$ Bathers were exhorted to live happily, avoid anxiety and too much study, and enjoy conversation, music, and good company. The Marquis of Mantua was thus attended at Caldiero in 1524 by a

\footnotetext{
22 Bacci, op. cit., note 3 above, p. 80.

${ }^{23}$ Ventura Minardo, Compendio delle regole date da diversi eccellentissimi autori intorno ai bagni di Caldiero, Verona, 1594.

24 Ibid., especially f. 19r. "Di portar della carta ogn'un si avisa, se non che'l biasma sia della camisa".

${ }^{25}$ Bacci, op. cit., note 3 above, p. 90; idem, note 9 above, p. 16.
} 


\section{Italian Renaissance baths}

consort of musicians. He also found recreation in games of cards, and he gave a banquet for a hundred guests. ${ }^{26}$ At Lucca, Montaigne found the social season even more developed, and he himself gave two balls. ${ }^{27}$ A certain moral freedom was also an attraction of the baths. The gouty Cardinal Luigi d'Este was said to have lurked at the Paduan baths more for the proximity of the women of Venice than for his health, while a contemporary Italian proverb gave a new interpretation to the baths' reputation as a cure for sterility: "If you want your wife to conceive, send her to the baths, and stay at home yourself." 28 But there was nothing to match the open sexuality of the Swiss Leukerbad portrayed by Hans Bock in the late sixteenth century, for Italian baths tended to be segregated, and the bathers usually clothed. $^{29}$

Although bathing was meant to be pleasant, the reverse was often the case. The purging effect of many waters was itself a discomfort, for the intention was usually to continue until the water ran clear from both excretory channels. Leonora d'Este, sister of the Duke of Ferrara, fainted in her overheated bath of Abano water in $1562 .{ }^{30}$ Montaigne was put off the baths at Viterbo by a patient's graffiti cursing the doctor who had sent him there where his illness had only got worse. ${ }^{31}$ The Marquis of Mantua, whose experience at Caldiero in 1524 has been described in rich detail by David Chambers, seems also to have endured, rather than enjoyed, the experience. Suffering from retention of urine, he yet managed to take up to eleven glasses a day, although on some occasions vomiting ensued, so that he had to drink still more to make up what he had lost. He topped up his cure with shower therapy at Abano, but there, too, he wearied of the treatment, every hour-long session seeming a thousand times longer. ${ }^{32}$ Another patient, Piermatteo Corvini, wrote a similarly disgruntled letter from Orvieto in 1557: "I have been at the baths for many days and have drunk a good lot of water, and I think I am worse, not better. But the doctors say this is a good sign ... and that I should have faith in them . . . If, by God's will, I get out of here, I intend to make some votive offering." 33

Angling for a patron to restore and improve the baths in England, William Turner compared them unfavourably with the well-appointed spas of Germany and Italy. Sharing as he did a belief in a renaissance of balneology in "this our lightye and learned tyme", it is not surprising that he looked to Italy as a model of what should be done. Yet in reality Italian baths retained a rustic, not to say primitive, character throughout the sixteenth century. Just as Renaissance physicians failed, by and large, to impose their balneological disciplines on the general public, so the hope of reviving

\footnotetext{
${ }^{26}$ David S. Chambers, 'Federico Gonzaga ai bagni di Caldiero (1524)', Civiltà Mantovana, n.s., 1984, 4: 45-61.

${ }^{27}$ Montaigne, op. cit. note 21 above, pp. 432-4.

28 Ibid., pp. 142, 441. "Chi vuol che la sua donna impregni, mandila al bagno, e non ci vegni".

29 Bock's painting is reproduced in A. S. Lyons and R. J. Petrucelli, Medicine. An illustrated history, New York, Harry N. Abrams, 1978, p. 338. On bathing dress at Caldiero, see Minardo, op. cit., note 23 above, f. $24 r$.

${ }^{30}$ G. Campori and A. Solerti, Luigi, Lucrezia e Leonora d'Este, Turin, 1888, p. 146.

31 Montaigne, op. cit., note 21 above, p. 523.

32 Chambers, op. cit., note 26 above.

${ }^{33}$ Wellcome Institute, Western MS. 5426. Piermatteo Corvini to Giustino Mandosio, 20 June 1557.
} 


\section{Richard Palmer}

the classical bath house proved no more than a pipe-dream. ${ }^{34}$ In 1580 , when Montaigne visited the hot, sulphurous springs of Abano, perhaps the most famous, and certainly the most written-up spa in Italy, he found only two or three small houses, poorly fitted out, which were supplied with water for indoor bathing. ${ }^{35}$ The main public bath was open to the elements, which put it out of use in bad weather. "Why, oh why", asked Falloppia in his lectures, "doesn't the Venetian government have it covered?"36 Much of the water was used to service a mill, perhaps unique in being driven by hot water. ${ }^{37}$ Even by the eighteenth century Abano had not developed overmuch; the mill was still turning, and in the centre of the thermal area was still a bath for horses. ${ }^{38}$

Other Paduan baths were even less developed. In 1554, in the wake of De balneis, the Venetian authorities had to send in workers to root out the brambles which enveloped them. ${ }^{39}$ At S. Pietro Montagnone, Montaigne also found two or three houses for the sick, again quite rough and ready, so that he would not send his friends there. S. Bartolomeo, still in the Padovano, had even less facilities. Although its hot, black mud was world-famous for gout and nervous disorders, it boasted only a disused paupers' hospital for the use of its visitors. ${ }^{40}$ Small wonder that, on her visit to the baths in 1562, Leonora d'Este chose to reside in Padua and have the water and mud brought to her daily from the baths. ${ }^{41}$

There was, in fact, a considerable export of waters from the baths to the towns. Falloppia was amazed to find water from the Bagno alla Villa at Lucca as far afield as Venice, and, indeed, Montaigne recorded that infinite quantities were sold every day throughout Italy. ${ }^{42}$ The water of Abano was likewise available to Ludovico Pasini in Pesaro, while Cosimo de' Medici enjoyed in Tuscany a supply of the Paduan mud of San Bartolomeo. ${ }^{43}$ Taking the waters at home was a convenient option for the invalid; but the brisk trade in water and mud was also a reflection of the discomforts which were sometimes a feature of life at the baths. "Now you should know", wrote Leonardo Fioravanti, "that going to the baths means the greatest expense, travail, and fatigue for the patient". He himself, influenced by the Paracelsan movement, preferred artificial baths, prepared at home, to the sometimes malodorous products of nature. ${ }^{44}$

The principal bath at Caldiero was at least walled around and paved in the early

\footnotetext{
${ }^{34}$ Relevant here is Falloppia's observation of a difference between ancient and modern bathing practices. The former, he noted, were largely concerned with hygiene; the latter exclusively with therapeutics (Falloppia, op. cit., note 2 above, f. 37v.).

${ }^{35}$ Montaigne, op. cit., note 21 above, p. 138.

${ }^{36}$ Falloppia, op. cit., note 2 above. f. 59 r.

${ }^{37}$ See the earlier drawing reproduced in Domenico Vandelli, De thermis agri patavini, Padua, 1761. The drawing is also reproduced in the exhibition catalogue I secoli d'oro della medicina. 700 anni di scienza medica a Padova, Modena, Panini, 1986, p. 170.

38 See the plates in S. Mandruzzato, Dei bagni di Abano, Padua, 1798-1804.

39 Padua, Archivio Antico dell'Università, filza 736, f. 218 r.-v., a ducale of 3 Nov. 1554.

${ }^{40}$ Montaigne, op. cit., note 21 above, pp. 138-46.

${ }^{41}$ Campori and Solerti, op. cit., note 30 above, pp. 143-7. Printed here are accounts of Leonora's expenses at the baths on water and mud, a useful source on quantities and prices.

${ }^{42}$ Falloppia, op. cit., note 2 above, f. 82r.; Montaigne, op. cit., note 21 above, pp. 430-1.

${ }^{43}$ De balneis, op. cit., note 5 above, f. 197v. Bacci, op. cit., note 3 above, p. 311.

44 Leonardo Fioravanti, De' capricci medicinali, Venice, 1582, f. 17r.
} 


\section{Italian Renaissance baths}

sixteenth century, so that it was protected from the winds and from the incursion of animals. ${ }^{45}$ Yet it was still prone to fall into disrepair and even abandonment when, for instance, neglect of its drainage channels rendered the water unfit for use. ${ }^{46}$ Zuane Banda, a local landowner and would-be franchiser, blamed the peasants who had charge of it. He claimed in 1585 that they were more concerned with profit than with keeping the baths clean and in repair, and that their rough manners were unwelcoming to visitors. ${ }^{47}$ Only at the Bagni di Lucca was Montaigne satisfied. There, in beautiful surroundings (Falloppia called it not villa but paradise), he found 30 or $\mathbf{4 0}$ good houses for the bathers, and the Bagno alla Villa covered, if somewhat dark inside. ${ }^{48}$ These features were modest enough, and indeed, sixteenth-century illustrations of the Bagno alla Villa confirm that it was neither large nor architecturally impressive. ${ }^{49}$ Even the best of Italian baths were a far cry from the Roman bath houses, with their suites of rooms for different types and temperatures of bathing; these the Renaissance balneologists admired, but never managed to imitate or revive.

Yet although the bathing establishments were modest, there can be no doubting the high esteem in which medicinal waters were held by physicians and self-medicating laymen alike. A need for therapy at the baths might be accepted as grounds for a nun to leave her convent, ${ }^{50}$ or for a surgeon to get leave of absence from a hospital. ${ }^{51}$ Gabriele Morosini, Venetian podestà at Verona, even declined to attend the Venetian Senate to report on his term of office. He argued that he needed, rather, to recover from the strain of office (and the kidney stone which had resulted) by taking a cure at Caldiero. ${ }^{52}$ For some, water therapy was probably a first choice. For others it was one of many resources to be tried out in the long struggle with chronic disease, and the baths certainly had a reputation as the doctors' last resort. ${ }^{53}$

All the sources affirm that the baths were popular and well-attended. Many travelled far to use them, and, indeed, distance added to their appeal. Montaigne discovered that the people of Lucca never went to their local spa, just as the locals at Loreto never went on pilgrimage to the Holy House. ${ }^{54}$ Although, however, they were

\footnotetext{
${ }^{45}$ Chambers, op. cit., note 26 above, describes fifteenth- and early sixteenth-century measures by the Council of Verona concerning the baths. An eighteenth-century print, showing the baths at Caldiero little changed, is reproduced in Maria Teresa Berrutti, Catalogo delle pubblicazioni sulle acque minerali d'Italia, Rome, Istituto Superiore di Sanità, 1972.

46 In 1535, for instance, the Council of Verona set up a commission to deal with the "infectio et devastatio balneorum Calderii", Verona, Archivio di Stato, Archivio del Comune, Reg. 610, f. 152r. In 1585 the baths were again reported to be fetid and abandoned (Ibid., busta 252, fasc. 2973).

47 Ibid.

${ }^{48}$ Montaigne, op. cit., note 21 above, pp. 401-6.

49 Maurizio Burlamacchi, Le antiche case del Bagno alla Villa in terra di Lucca, Florence, Libreria Seeber, 1969, pp. 97-101, 149-54.

${ }^{50}$ Rome, Archivio Segreto Vaticano, Dispacci del Nunzio a Venezia, filza 25, 1584-85, f. 167r. The Nunzio sought a licence for a nun of the Priuli family to go to the baths of Abano to treat a dangerous illness.

5 Udine, Seminario Patriarcale, Ospedale di Santa Maria della Misericordia dei Battuti, Terminazioni 1561-76, f. 295 r., 10 July 1575.

52 Istituto di Storia Economica dell'Università di Trieste, Relazioni dei Rettori Veneti in Terraferma, vol. 9, Podestaria e Capitanato di Verona, Milan, 1977, pp. 17-18, Aug. 1558.

53 Bacci, op. cit., note 3 above, p. 95 . "Ultima medicorum appellatio Balnea".

54 Montaigne, op. cit., note 21 above, p. 511.
} 


\section{Richard Palmer}

part of nature's bounty, medicinal waters were not readily available to all sections of the community. An artisan would not easily find leisure for a cure, which was normally a lengthy business. Furthermore, neither water nor mud were free, for the baths were usually run by entrepreneurs who contracted their management from the local comune. Bacci's patrician remark that the baths were appropriate only for the rich therefore had a certain point, and much of what is known of Italian baths derives from the bathing experiences of Italy's ruling families, such as the Este, Medici or Gonzaga. ${ }^{55}$ Yet the poor seem not to have been totally excluded. The Marquis of Mantua's accounts included alms given to poor bathers at Caldiero, ${ }^{56}$ and in 1581 the Hospital of San Francesco at Padua agreed to send three paupers to the baths at its own expense, since they could not be cured except by mud therapy. ${ }^{57}$ Sometimes, too, the profusion of springs in a locality worked in favour of the disadvantaged. At Pisa, for instance, Montaigne discovered that the numerous baths included one used by the common people, which was good for liver and kidney complaints. ${ }^{58}$

Finally, acknowledgement must be made of the cures which were regularly reported as a result of taking the waters. An old bagnarolo such as Vincenzo da Sarravalle, 40 years a bath attendant at Caldiero like his father before him, could relate a string of successful cures. ${ }^{59}$ Even the scholarly De balneis included an index of miraculous recoveries. Yet even here there was little satisfaction for the physician. Three kinds of men, wrote Andrea Bacci, went to the baths. First were the thoughtless, who tried to save expense by not consulting the doctor, only to find that the baths were the scourge of the skinflint. Second were those whose lives were despaired of by the doctor. Mostly they died, blaming both the doctor and the baths. Finally there were those who went to the baths with the advice of the doctor, and who returned consoled and sometimes cured. But did they thank the doctor? No, they praised the baths. ${ }^{60}$

\footnotetext{
55 On the Este family, Campori and Solerti, op. cit., note 30 above; on the Medici, Andrea Corsini, Malattia e morte di Lorenzo de'Medici, Florence, 1913, especially pp. 38-51, 71-4; on the Gonzaga, Chambers, op. cit., note 26 above.

56 Ibid.

${ }_{57}^{5}$ Padua, Archivio di Stato, Ospedale di San Francesco, Acta 1553-1584, ff. 176r.-177v.

58 Montaigne, op. cit., note 21 above, pp. 493-5.

59 Minardo, op. cit., note 23 above, ff. $9 v$. -11 r.

60 Bacci, op. cit., note 9 above, p. 11. For an example, see Litolfi's grateful verses in praise of the Bagni di Lucca, written in 1554: Ernst Gombrich and David Chambers, "Annibale Litolfi, a sixteenth-century nature lover', Renaissance Studies, 1988, 2: 321-6.
} 